Tropical Journal of Pharmaceutical Research May 2017; 16 (5): 1195-1199

ISSN: $1596-5996$ (print); 1596-9827 (electronic)

(C) Pharmacotherapy Group, Faculty of Pharmacy, University of Benin, Benin City, 300001 Nigeria.

All rights reserved.

Available online at http://www.tjpr.org

Original Research Article

http://dx.doi.org/10.4314/tjpr.v16i5.30

\title{
Self-medication with antibiotics in Sana'a City, Yemen
}

\author{
Sami Mohammed Albawani, Yahaya Bin Hassan*, Noorizan Abd-Aziz and \\ Shubashini Gnanasan \\ Faculty of Pharmacy, Department of Pharmacy Practice, University Teknologi MARA, Malaysia
}

*For correspondence: Email: profyahaya@gmail.com; Tel: +60195515611

Sent for review: 4 November 2016

Revised accepted: 9 April 2017

\begin{abstract}
Purpose: To determine the prevalence of self-medication with antibiotics in Sana'a City, Yemen and its associated risk factors.

Methods: In a descriptive cross-sectional study, a self-administered questionnaire was developed and distributed among consumers attending community pharmacies in Sana'a city, Yemen. Chi-square test was used to identify the risk factors associated with self-medication with antibiotics.

Results: The prevalence of antibiotics use during self-medication was $87.1 \%$ (58.2 \% of males and $41.8 \%$ of females). Among all respondents, only $49.5 \%$ were aware of bacterial resistance due to antibiotic use. The majority of illness/symptoms treated with antibiotics during self-medication were common cold, cough, diarrhea and fever. The high cost of physician consultation was the main reason for self-medication with antibiotics. The most common source of information was community drug dispensers. Although different factors were assessed, no association could be found between factors like age, gender, material status, educational status, employment, monthly income or knowledge regarding bacterial resistance and self-medication with antibiotics.

Conclusion: Self-medication with antibiotics is high among consumers in Sana'a City, Yemen.
\end{abstract}

Keywords: Self-medication, Antibiotics, Community pharmacies, Sana'a City, Yemen.

Tropical Journal of Pharmaceutical Research is indexed by Science Citation Index (SciSearch), Scopus, International Pharmaceutical Abstract, Chemical Abstracts, Embase, Index Copernicus, EBSCO, African Index Medicus, JournalSeek, Journal Citation Reports/Science Edition, Directory of Open Access Journals (DOAJ), African Journal Online, Bioline International, Open-J-Gate and Pharmacy Abstracts

\section{INTRODUCTION}

Self-medication is the use of drugs to treat selfdiagnosed disorders or symptoms, or the intermittent or continued use of a prescribed drug for recurrent disease or symptoms. Selfmedication, as one element of self-care, is the selection and use of medicines by individuals to treat self-recognized illnesses or symptoms [1]. It is an important response to illness that can be controlled in its early stage. However, the irrational use of medications may lead to harmful consequences including drug toxicity and drug interactions [2]. In addition, the resistance of microorganisms has been attributed to the misuse or overuse of antibiotics.
Several studies in developed [3] and developing $[4,5]$ countries indicate that the use of antibiotics during self-medication is a common practice worldwide. The prevalence of self-medication with antibiotics has been found to be more in low income countries and it has been shown to be significantly related to many factors like availability and easy access to antibiotics, lack of access to health care [6], inappropriate use [7], poor awareness [8], poor regulation [9], lack of supervision by health professionals [7], high occurrence of infectious diseases and increased antibiotic prescription [10]. Some other studies reported fever, common cold, sore throat and diarrhea as most common reasons for selfmedication with antibiotics $[11,12]$. 
Antimicrobial resistance due to the misuse of antibiotics is a current problem especially in developing countries [13]. Self-medication with antibiotics can lead to treatment failure, drug toxicity, prolonged hospitalization and may lead to death [14]. This study was carried out to determine the prevalence of antibiotics use during self-medication practice and its associated risk factors in Sana'a City.

\section{METHODS}

In a descriptive cross-sectional study, a selfadministered questionnaire was developed and distributed among consumers attending community pharmacies in Sana'a city, the capital of Yemen. Permission to conduct this study was approved by the research ethics committee in UiTM university, health office in Sana'a City and the community pharmacies included in this study. A convenience sampling method was used to distribute 363 questionnaires were to consumers attending 10 selected community pharmacies. The pharmacies were carefully selected to represent different areas in Sana'a City.

Among other questions, the respondents were asked about their socio-demographic characteristics, symptoms or illness treated with antibiotics, reasons for self-medication with antibiotics, source of information or advice for self-medication and their perception about the safety of antibiotics. All data obtained were analyzed using SPSS statistical software version 21. The risk factors associated with selfmedication with antibiotic were identified using chi-square test and multiple logistic regressions were used to identify.

\section{RESULTS}

A total of 363 questionnaires were completed and collected, out of which 204 (56.2\%) were males and $159(43.8 \%)$ were females. The mean age of the respondents was $28.6 \pm 7.7$ (range 18 - 65). Table 1 shows the descriptive analysis of the variables. The majority of the respondents had university education, low income, access to medical centers and did not have medical insurance. The prevalence of selfmedication with antibiotic in the previous six months was found to be $87.1 \%(58.2 \%$ males and $41.8 \%$ females). The use of antibiotics and the awareness of participants about bacterial resistance are shown in Figure 1. Majority (87.1) of respondents reported the use of antibiotics during self-medication. Among all respondents, only $49.5 \%$ reported that they are aware of bacterial resistance due to antibiotic use.
The majority of illness/symptoms which were treated with antibiotics during self-medication are common cold (88.4\%), cough (73.5\%), diarrhea (40.3\%), and fever (19.4\%). The high cost of physician consultation $(69.8 \%)$ was found to be the main reason for the respondents to use antibiotics during self-medication. Other reasons like the lack of access to health care (55.5\%), time $(43.3 \%)$ and lack of insurance $(20.4 \%)$ were reported as well. The common sources of information were the community drug dispensers $(92.3 \%)$ followed by family members $(22.7 \%)$, personal choice (11.3), old prescription (7.5\%) and friends (5.7\%) (Figure 1).

The bivariate analysis was used to identify the risk factors associated with the use of antibiotics during self-medication as shown in table 2 . Such factors investigated include, gender, marital status, education status, employment, income, availability of medical insurance and medical access.

Table 1: Socio-demographics of respondents

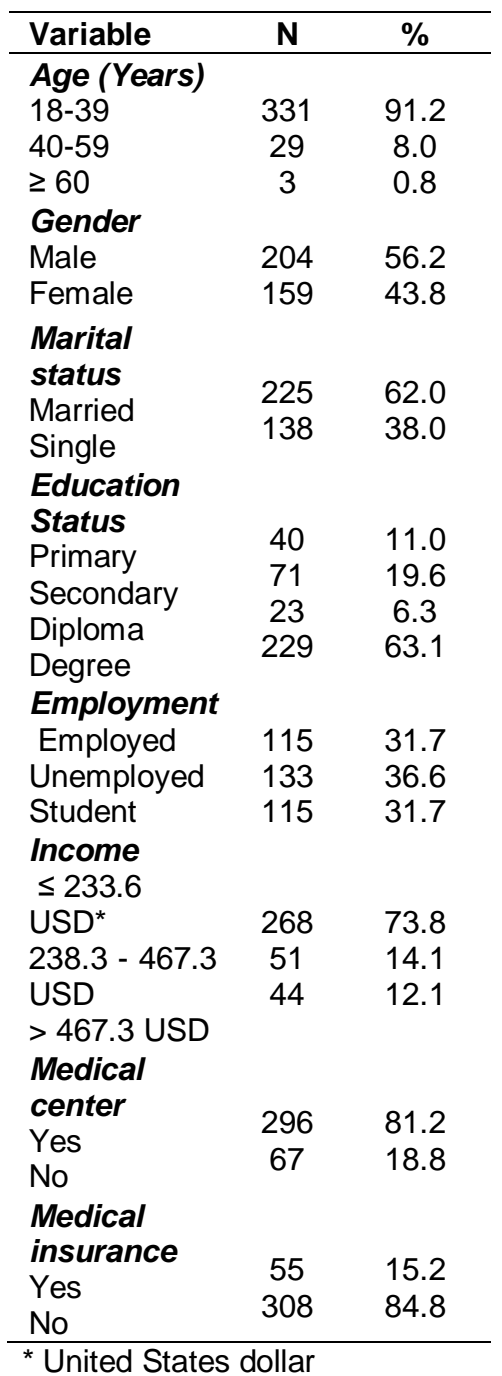

Trop J Pharm Res, May 2017; 16(5): 1196 


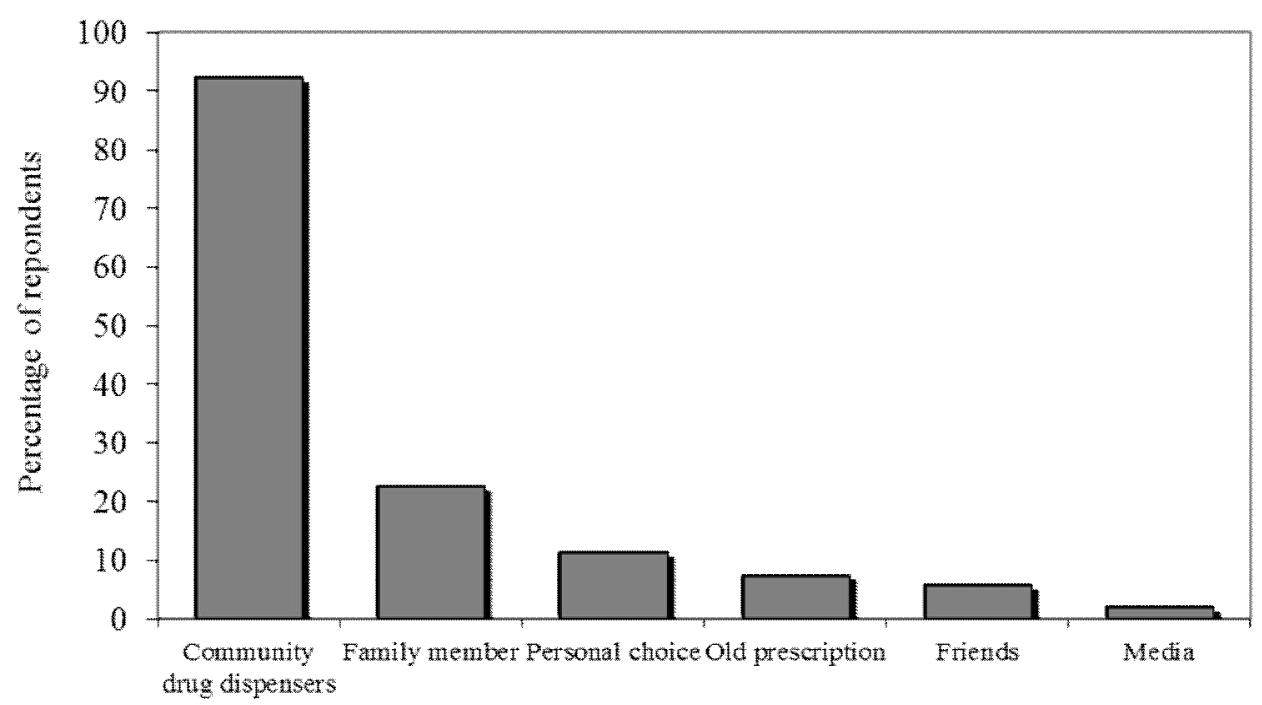

Figure 1: Sources of information/advice for self-medication with antibiotics

Table 2: Bivariate analysis (Chi square test)

\begin{tabular}{|c|c|c|c|c|c|c|c|}
\hline \multirow[b]{2}{*}{ Variable } & \multirow[b]{2}{*}{ Yes (\%) } & \multirow[b]{2}{*}{ No (\%) } & \multicolumn{5}{|c|}{$95 \% \mathrm{Cl}$} \\
\hline & & & $\begin{array}{l}\text { Chi- } \\
\text { Square }\end{array}$ & $\begin{array}{l}\text { Odds } \\
\text { Ratio }\end{array}$ & Lower & Upper & $\begin{array}{l}P \\
\text { value }\end{array}$ \\
\hline \multicolumn{8}{|l|}{ Age (years) } \\
\hline $18-39$ & $286(86.4)$ & $45(13.6)$ & 1.511 & & & & 0.470 \\
\hline $40-59$ & $27(93.1)$ & $2(6.9)$ & & & & & \\
\hline$\geq 60$ & $3(100.0)$ & $0(0.0)$ & & & & & \\
\hline \multicolumn{8}{|l|}{ Gender } \\
\hline Male & $184(90.2)$ & $20(9.8)$ & 4.084 & 1.882 & 1.012 & 3.498 & 0.063 \\
\hline Female & $132(83.0)$ & $27(17.0)$ & & & & & \\
\hline \multicolumn{8}{|l|}{ Marital status } \\
\hline Married & $200(88.9)$ & $25(11.1)$ & 1.77 & 1.517 & 0.819 & 2.812 & 0.183 \\
\hline Single & $116(84.1)$ & $22(15.9)$ & & & & & \\
\hline \multicolumn{8}{|l|}{ Educational status } \\
\hline Primary & $36(90.0)$ & $4(10.0)$ & 8.171 & & & & 0.059 \\
\hline Secondary & $68(95.8)$ & $3(4.2)$ & & & & & \\
\hline Diploma & $21(91.3)$ & $2(8.7)$ & & & & & \\
\hline Degree & $191(83.4)$ & $38(16.6)$ & & & & & \\
\hline \multicolumn{8}{|l|}{ Employment } \\
\hline Employed & $103(89.6)$ & $12(10.4)$ & 2.988 & & & & 0.224 \\
\hline Unemployed & $118(88.7)$ & $15(11.3)$ & & & & & \\
\hline Student & $95(82.6)$ & $20(17.4)$ & & & & & \\
\hline \multicolumn{8}{|l|}{ Income } \\
\hline$\leq 233.6$ USD* $^{*}$ & $229(85.4)$ & $39(85.4)$ & 2.526 & & & & 0.283 \\
\hline $238.3-467.3$ USD & $46(90.2)$ & $5(9.8)$ & & & & & \\
\hline$>467.3$ USD & 41 (93.2) & $3(6.8)$ & & & & & \\
\hline \multicolumn{8}{|l|}{ Medical insurance } \\
\hline Yes & $49(89.1)$ & $6(10.9)$ & 0.239 & 1.254 & 0.505 & 3.113 & 0.625 \\
\hline No & $267(86.7)$ & $41(13.3)$ & & & & & \\
\hline \multicolumn{8}{|l|}{ Medical center } \\
\hline Yes & $256(81.9)$ & $57(18.1)$ & 0.928 & 1.350 & 0.732 & 2.489 & 0.335 \\
\hline No & $40(80.0)$ & $10(20.0)$ & & & & & \\
\hline \multicolumn{8}{|l|}{ Bacterial resistance } \\
\hline Yes & $158(88.8)$ & $20(11.2)$ & 0.908 & 1.350 & 0.727 & 2.507 & 0.341 \\
\hline No & $158(85.4)$ & $27(14.6)$ & & & & & \\
\hline
\end{tabular}

* United States dollar

\section{DISCUSSION}

The prevalence of self-medication with antibiotics among consumers in Sana'a City was high when compared to other countries. It was found that $87.1 \%$ of respondents used antibiotics during self-medication. In similar studies, the use of antibiotics ranged from 7.3 to $60 \%[3,4,7]$. The 
reason for such variation may be due to the different socio-economic status, education, culture and health care regulations in each country $[4,17]$. It was reported that the rational use of medicines is not acknowledged by the laws and policies in Yemen [18]. In Yemen, it is generally accepted to buy antibiotics from community pharmacies and drug stores without a prescription.

It is essential for community pharmacists to have an adequate knowledge to promote safe and rational medication use among consumers. However, the profession of pharmacy was reported by the ministry of health in Yemen to be less trustworthy and less reliable [18]. Moreover, almost half of the study population were reported to be not aware of antibacterial resistance. Such results were similar to another study were $63.1 \%$ of population were found to be not aware of antibiotic resistance [5]. This may suggest that poor medication knowledge and the lack of awareness among consumers may lead to the irresponsible use of antibiotics.

Viral infections and minor illnesses such as upper respiratory tract infections and common colds are frequently treated with antibiotics $[4,17]$. Such irresponsible practice increases bacterial resistance to antibiotics, raises the cost of treatment and may lead to treatment failure eventually. In this study, the respondent showed a similar attitude during self-medication with antibiotics. They mainly used antibiotics for the treatment of common cold, cough, diarrhea and fever. Similar findings have been reported in other studies as well $[7,15,16]$.

The most common reason for using antibiotics during self-medication was the high cost of physician consultation. This has also been found to be the main reason for such practice in other studies $[4,5]$. Other reasons like the lack of access to health care, time and lack of insurance were found to be reported by other studies as well [5]. The most common source of information during self-medication was the community drug dispensers which is similar to other studies $[4,7,16]$. This was expected as pharmacies are the main source of medications. Other sources like family members, personal choice and old prescription were found to be common in other studies as well $[15,17]$.

The bivariate analysis was used to identify the risk factors associated with the use of antibiotics during self-medication. Although different factors were assessed for an association with the use of antibiotics, no association could be found between factors like age, gender, material status, educational status, employment, monthly income or knowledge regarding bacterial resistance and self-medication with antibiotics. In a similar study, association between the demographic factors and the use of antibiotics was not found as well [5].

The high prevalence of antibiotic use during selfmedication practice among consumers may be related to the fact that majority have a very low income with no access to medical insurance. Like other developing countries, the health care infrastructures in Yemen were reported to be less than adequate and the quality of health care services was stated to be far from satisfactory [19]. In addition, the economic status of the majority of Yemeni families [4], the insufficient health authority inspection on community pharmacies and the inefficient medical supervision may influence such practice [18].

Since community pharmacists were the main source of information/advice in this study, their role must be highlighted and closely regulated and controlled by health authorities. In addition, the variation in patient's level of understanding about their medications emphasized the importance of professional guidance to choose the right medication for each condition [20]. This even suggests that consumers should have a basic knowledge about medication and health care to avoid any misuse of medication.

\section{Limitation of the study}

Although Sana'a City is the capital of Yemen, generalization of the results may be questioned. However, the researcher included all city districts for a better representation of the sample.

\section{CONCLUSION}

The use of antibiotics in self-medication is high among the population in Sana'a City, Yemen. Educational and regulatory interventions from health authority in Yemen are needed. Educational health campaigns are required to increase awareness and health care education among population for a safe and responsible practice. In addition, enforcement of existing laws which regulate drug use, prescribing and dispensing is essential to control the misuse of antibiotics.

\section{DECLARATIONS}

\section{Acknowledgement}

This study was support by grant no. 600IRMI/DANA 5/3/BESTARI (19/2016), University 
Teknology MARA. I would like to thank Professor Sami Al-Dubai and Dr Al-abed Ali for their valued help in data analysis.

\section{Conflict of Interest}

No conflict of interest associated with this work.

\section{Contribution of Authors}

The authors declare that this work was done by the authors named in this article and all liabilities pertaining to claims relating to the content of this article will be borne by them.

\section{Open Access}

This is an Open Access article that uses a funding model which does not charge readers or their institutions for access and distributed under the terms of the Creative Commons Attribution License (http://creativecommons.org/licenses/by/ 4.0) and the Budapest Open Access Initiative (http://www.budapestopenaccessinitiative.org/rea d), which permit unrestricted use, distribution, and reproduction in any medium, provided the original work is properly credited.

\section{REFERENCES}

1. World Health Organization. Guidelines for the regulatory assessment of Medicinal Products for use in selfmedication; vol 1. WHO/EDM/QSM/00.1. Geneva, Switzerland: WHO; 2000

2. Arzi A, Ashtarinezhad A, Sarahroodi S, Sawalha AF. Antibiotic self-medication among Southern Iranian University students. Int J Pharmacol 2010; 6 (1): 48-52.

3. Richman PB, Garra G, Eskin B, Nashed AH, Cody R. Oral antibiotic use without consulting a physician: a survey of ED patients. Am J Emerg Med 2001; 19 (1): 57-60.

4. Mohanna M. Self-medication with antibiotic in children in Sana'a city, Yemen. Oman Med J 2010; 25 (1): 41-43.

5. Shah SJ, Ahmad H, Rehan RB, Najeeb S, Mumtaz M, Jilani MH, Rabbani MS, Alam MZ, Farooq S, Kadir MM. Self-medication with antibiotics among non-medical university students of Karachi: a cross-sectional study. BMC Pharmacol Toxicol 2014; 15: 74.

6. Khan SJ, Amanullah, Khan S, Shah N. Self-medication with antibiotics in urban areas of Peshawar. Gomal $J$ Med Sci 2011; 9: 19-22.

7. Widayati $A$, Suryawati S, de Crespigny C, Hiller JE. Selfmedication with antibiotics in Yogyakarta City Indonesia: a cross sectional population-based survey. BMC Res Notes 2011; 4: 491.
8. Zhu X, Pan H, Yang Z, Cui B, Zhang D, Ba-Thein W. Self-medication practices with antibiotics among Chinese university students. Public health 2016; 130: 78-83.

9. Fadare JO, Tamuno I. Antibiotic self-medication among university medical undergraduates in Northern Nigeria. $J$ Public Health Epidemiol 2011; 3: 217-220.

10. Grigoryan L, Burgerhof JG, Haaijer-Ruskamp FM, Degener JE, Deschepper R, Monnet $D L$ et al. Is selfmedication with antibiotics in Europe driven by prescribed use? J Antimicrob Chemother 2007; 59: 152156.

11. Nalini GK. Self-Medication among Allopathic medical Doctors in Karnataka, India. Br J Med Pract 2010; 3: 325.

12. Le TH, Ottosson E, Nguyen TKC, Kim BG, Allebeck P. Drug use and self-medication among children with respiratory illness or diarrhea in a rural district in Vietnam: a qualitative study. J Multidiscip Health 2011; 4: 329-336.

13. Knobler SL, Lemon SM, Najafi M, Burroughs $T$. The Resistance Phenomenon in Microbes and Infectious Disease Vectors: Implications for Human Health and Strategies for Containment. Workshop Summary, Institute of Medicine, Washington, DC: The National Academy Press (2003).

14. Maragakis LL, Perencevich EN, Cosgrove SE. Clinical and economic burden of antimicrobial resistance. Expert Rev Anti Infect Ther 2008; 6(5): 751-763.

15. Togoobaatar G, lkeda $N$, Ali $M$, Sonomjamts $M$, Dashdemberel S, Mori R, Shibuya K. Survey of nonprescribed use of antibiotics for children in an urban community in Mongolia. Bull World Health Organ 2010; 88(12): 930-936.

16. Awad A, Eltayeb I, Matowe L Thalib L. Self-medication with antibiotics and antimalarials in the community of Khartoum State, Sudan J Pharm Pharm Sci 2005; 8: 326-331.

17. Abasaeed A, Jiri V, Mohammed A, Ales K. Selfmedication with antibiotics by the community of $A b u$ Dhabi Emirate, United Arab Emirates. J Infect Dev Ctries 2009; 3: 491-497.

18. Pharmaceutical Country Profile of Yemen (PCPY), 2012 [cited March 20, 2015], from http://www.who.int/medicines/areas/coordination/coordin ation_assessment/en/index1.html.

19. Al-Shami AM, Mohamed Izham MI, Abdo-Rabbo A. Personalize Android Phone Evaluation of the Quality of Prescriptions with Antibiotics in the Government Hospitals of Yemen Healthcare. J Clin Diagn Res 2014; 5: 808-812.

20. Hughes L, Whittlesea C, Luscombe D. Patients' knowledge and perceptions of the side-effects of OTC medication. J Clin Pharm Ther 2002; 27: 243-248. 